\title{
Effects of alpha-tocopherol and dietary oxidized fish oil on the immune response of sea bass Dicentrarchus labrax
}

\author{
A. Obach, C. Quentel, F. Baudin Laurencin \\ CNEVA-LPAA - Centre National d'Etudes Vétérinaires et Alimentaires, Laboratoire de Pathologie des Animaux Aquatiques, \\ BP 70, F-29280 Plouzané (Brest), France
}

\begin{abstract}
Sea bass weighing about $35 \mathrm{~g}$ were reared on 6 experimental diets differing in the level of alpha-tocopherol (vitamin E) supplementation $\left(0,40\right.$ or $300 \mathrm{mg} \mathrm{kg}^{-1}$ ) and fish oil quality (fresh or oxidized). After $35 \mathrm{wk}$, group comparisons of haematological parameters were made and alpha-tocopherol levels in anterior kidney, spleen, and thymus were assessed in pooled samples. Non-specific immune factors assayed were: (1) plasma lysozyme and complement activities, (2) natural haemolysis of sheep red blood cells (SRBC), and (3) chemiluminescence (CL) response of head kidney phagocytes. Humoral antibody production was also assessed for each group after immunisation with Vibrio anguillarum 408. Resistance to bacterial infection was assessed comparatively according to diet. The levels of alphatocopherol in the different tissues were a function of the dietary vitamin E concentrations and were lower when oxidized fish oil was added to the diet. Erythrocyte fragility was raised in vitamin $\mathrm{E}$ depleted groups as well as in fish fed diets containing oxidized oil. Disease resistance, antibody response to $V$. anguillarum antigen, and haemolytic activity of sera were not affected by dietary treatment. Plasma lysozyme activity was lower in groups fed diets containing oxidized oil or not supplemented with vitamin $E$, and complement activity was higher in the fish that were fed the diet containing fresh oil and $300 \mathrm{mg}$ vitamin $\mathrm{E} \mathrm{kg}^{-1}$. One month after vaccination, the $\mathrm{CL}$ peak response of head kidney phagocytes, stimulated by opsonized zymosan, was significantly lower in the fish that were fed the diet containing oxidized oil and not supplemented with vitamin $E$.
\end{abstract}

\section{INTRODUCTION}

Diets for cultured marine fish contain high levels of polyunsaturated fatty acids (PUFA) derived from marine fish oils. These fatty acids are especially prone to oxidative damage during diet preparation and storage. Products derived from lipid peroxidation may be absorbed after decomposition in the intestinal tract and transported to tissues, where they may induce adverse effects (Hata et al. 1986). In homeotherms, these effects are characterized by deterioration of tissue lipids, inactivation of enzymes, and destruction of biological membranes (Kaneda \& Miyazawa 1987). Because fish contain high concentrations of highly unsaturated fatty acids, they are vulnerable to lipid peroxidation and to tissue damage resulting from lipid peroxidation (Lall 1988).

Alpha-tocopherol (vitamin E) is best known for its antioxidant properties and has been demonstrated to be an essential dietary component for several fish species (Woodall et al. 1964, Watanabe et al. 1970, Murai \& Andrews 1974, Poston et al. 1976). Requirements for alpha-tocopherol are affected by other dietary factors such as the presence of oxidized oil in the diet and the dietary lipid level (Hung et al. 1981, Cowey et al. 1984)

In recent years, vitamin $E$ has been demonstrated to be important for the immune response in various species of animals in which it appears to influence both humoral and cellular factors. Supplemental vitamin E enhanced antibody production against a variety of particulate or soluble antigens by promoting increased proliferation of antibody-producing cells (Tengerdy et al. 1973) and by stimulating the response to T-cell mitogens as well as the mixed lymphocyte response to murine spleen cells (Corwin \& Gordon 1982). 
Supplementation with alpha-tocopherol also increased the phagocytic activity of peritoneal macrophages (Heinzerling et al. 1974) and resistance to bacterial infections (Nockels 1979 . Likoff et al. 1981). In fish, the impact of vitamin $E$ on immune functions has also been studied. Blazer \& Wolke (1984) showed that both T-cell (migration inhibition factors) and B-cell (plaqueforming cell)-mediated responses were compromised in rainbow trout Oncorhynchus mykiss W. fed low vitamin $\mathrm{E}$ diets. Humoral immunity and phagocytic ability of the peritoneal macrophages were also impaired in this species. Complement function was only affected in vitamin E depleted Atlantic salmon Salmo salar L. (Hardie et al. 1990). The impaiment of this function was related to increased mortality rate after challenge with Aeromonas salmonicida.

The present study was designed to evaluate the effect of diets containing oxidized or fresh oils and various levels of vitamin $\mathrm{E}$ on the immune response and disease resistance of sea bass Dicentrarchus labrax L. Complementary studies were conducted in our laboratory (Stéphan et al. 1991) to investigate the effect of such diets on histopathology as well as on plasma and tissue biochemistry.

\section{MATERIAL AND METHODS}

Animals and feeding. Sea bass, $35 \mathrm{~g}$ mean weight, were distributed randomly by groups of 32 into 12 experimental tanks (EWOS $1 \times 1$ ). These tanks were supplied with filtered and well-oxygenated seawater (salinity: $35 \%$; temperature: $20 \pm 1{ }^{\circ} \mathrm{C}$ ). Water renewal (150 $\left.\mathrm{l} \mathrm{h}^{-1}\right)$ was maintained throughout the experiment. The diets were prepared just before the start of the experiment by coating IFREMER rehydratable expanded pellets with an oily mixture (Table 1) representing $9.43 \%$ of the dry weight of the complete feed (PersonLe Ruyet et al. 1990). The composition of the basal diet is given in Table 2. Six experimental diets (F-0, F-40, F-300, Ox-0, Ox-40, Ox-300) were prepared, the compositions of which differed in the quality of added fish oil [fresh $(\mathrm{F})$ or oxidized $(\mathrm{Ox})$ ] and the level of tocopherol acetate: 0,40 or $300 \mathrm{mg} \mathrm{kg}^{-1}$ of feed. Oxidized oil was obtained by heating at $40^{\circ} \mathrm{C}$ with constant aeration (compressed air) for $30 \mathrm{~d}$, and this led to a marked increase in peroxide value $\left(280 \mathrm{mEq} \mathrm{kg}^{-1}\right.$ total dietary lipids) and a $16 \%$ decrease in $n-3$ fatty acids in the feed. The main features of the lipids contained in the experimental diets are shown in Table 3. Diets were considered as isoenergetic and the calculated energy content was $15.86 \mathrm{MJ}$ of metabolizable energy per $\mathrm{kg}$ diet. Diets were sealed in plastic bags and stored at
Table 1. Composition of the oil suspension ( $\%$ of dry matter contained in the complete feed)

\begin{tabular}{|c|c|}
\hline Cod liver oil ${ }^{\mathrm{a}}$ & 6.800 \\
\hline Soya lecithin & 1.000 \\
\hline Vitamin premix ${ }^{b}$ & 1.000 \\
\hline Choline $(50 \%)$ & 0.600 \\
\hline Ascorbic acid & 0.030 \\
\hline Tocopherol acetate & - \\
\hline 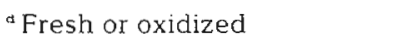 & \\
\hline 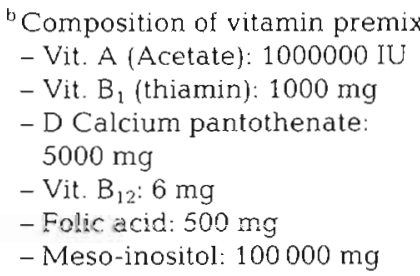 & $\begin{array}{l}\text { (per kg premix) } \\
\text { - Vit. } \mathrm{D}_{3}: 100000 \mathrm{IU} \\
\text { - Vit. } \mathrm{K}_{3}: 100 \mathrm{mg} \\
\text { - Vit. } \mathrm{B}_{2} \text { (riboflavin): } 2500 \mathrm{mg} \\
\text { - Vit. } \mathrm{B}_{6} \text { (pyridoxine): } 1000 \mathrm{mg} \\
\text { - Vit. DP (niacin): } 10000 \mathrm{mg} \\
\text { - Biotin: } 100 \mathrm{mg}\end{array}$ \\
\hline
\end{tabular}

$-20^{\circ} \mathrm{C}$ until use. The daily ration, periodically adjusted throughout the experiment, corresponded to approximately $1 \%$ of the body weight. Each diet was fed to duplicate tanks of fish during a $35 \mathrm{wk}$ period.

General protocol. After $35 \mathrm{wk}$ of feeding, blood samples were taken from 14 fish per dietary treatment ( 7 fish per tank) for determination of haematological and plasma parameters. Ten other fish from each diet

Table 2. Composition of the IFREMER rehydratable expanded pellet ( $\%$ of dry matter contained in the complete feed)

$\begin{array}{lc}\text { Norwegian capelin meal } & 42.0 \\ \text { Fish protein concentrate } & 8.0 \\ \text { Blood meal } & 4.0 \\ \text { Hydrolysed feather meal } & 3.0 \\ \text { Brewers' yeast } & 3.0 \\ \text { Corn gluten } & 7.0 \\ \text { Wheat meal } & 4.0 \\ \text { Wheat germ meal } & 3.0 \\ \text { Wheat middlings } & 4.0 \\ \text { DL-Methionine } & 0.45 \\ \text { Potato alpha starch liagel } & 11.0 \\ \text { Mineral premix } & 1.0 \\ & \\ \text { Composition of the mineral premix }(\%) & \\ \text { Potassium chloride } & 9.000 \\ \text { Potassium iodide } & 0.004 \\ \text { Dicalcium phosphate } & 50.000 \\ \text { Sodium chloride } & 4.000 \\ \text { Copper sulphate }(25 \% \mathrm{Cu}) & 0.300 \\ \text { Zinc sulphate }(34 \% \mathrm{Zn}) & 0.400 \\ \text { Cobalt sulphate (21 \% Co) } & 0.002 \\ \text { Iron sulphate }(20 \% \text { Fe) } & 2.000 \\ \text { Manganese sulphate }(30 \% \mathrm{Mn}) & 0.300 \\ \text { Calcium carbonate } & 21.500 \\ \text { Magnesium carbonate } & 12.400 \\ \text { Sodium fluoride } & 0.100\end{array}$


Table 3. Main features of the lipids contained in the 6 experimental diets: analytic results

\begin{tabular}{|c|c|c|c|c|c|c|}
\hline & $\mathrm{F}-\mathrm{O}$ & F-40 & $F-300$ & Ox-0 & Ox-40 & $0 x-300$ \\
\hline $\begin{array}{l}\text { Total lipids } \\
\text { (\% of wet feed) }\end{array}$ & 10.7 & 10.8 & 11.0 & 10.8 & 10.8 & 10.5 \\
\hline $\begin{array}{l}\text { Vitamin } E \\
\text { (mg kg-1 wet feed) }\end{array}$ & 2.0 & 49.8 & 321.4 & 2.2 & 41.9 & 283.9 \\
\hline $\begin{array}{l}\text { Peroxide value (POV) } \\
\text { (mEq kg } \mathrm{kg}^{-1} \text { of lipids) }\end{array}$ & 14.7 & 15.4 & 14.9 & 274.0 & 286.0 & 281.0 \\
\hline \multicolumn{7}{|l|}{$\begin{array}{l}\text { Main fatty acids } \\
\text { (\% of total fatty acids) }\end{array}$} \\
\hline $\mathrm{C} 14: 0$ & 5.16 & 5.01 & 5.06 & 5.43 & 5.48 & 5.49 \\
\hline C15:0 & 0.51 & 0.52 & 0.52 & 0.55 & 0.58 & 0.56 \\
\hline C16:0 & 16.16 & 16.16 & 16.25 & 17.43 & 17.59 & 17.56 \\
\hline C18:0 & 3.57 & 3.62 & 3.63 & 3.91 & 3.94 & 3.96 \\
\hline Total saturates & 25.92 & 25.85 & 26.00 & 27.92 & 28.18 & 28.14 \\
\hline C16:1 & 5.96 & 5.82 & 5.90 & 6.30 & 6.34 & 6.35 \\
\hline C18:1 & 2.60 & 2.56 & 2.61 & 2.78 & 2.86 & 2.75 \\
\hline C20:1 & 0.24 & 0.24 & 0.24 & 0.26 & 0.27 & 0.28 \\
\hline Total $n-7$ & 8.80 & 8.62 & 8.75 & 9.34 & 9.47 & 9.38 \\
\hline C18:1 & 13.53 & 13.47 & 13.47 & 14.46 & 14.46 & 14.54 \\
\hline $\mathrm{C} 20: 1$ & 4.07 & 3.94 & 3.87 & 4.19 & 4.20 & 4.12 \\
\hline $\mathrm{C} 22: 1$ & 0.46 & 0.46 & 0.36 & 0.51 & 0.48 & 0.44 \\
\hline C $24: 1$ & 0.76 & 0.73 & 0.92 & 0.90 & 0.85 & 0.83 \\
\hline Total n-9 & 18.82 & 18.60 & 18.62 & 20.06 & 19.99 & 19.93 \\
\hline $\mathrm{C} 18: 2$ & 8.18 & 8.25 & 8.28 & 8.78 & 8.80 & 8.83 \\
\hline C $20: 2$ & 0.17 & 0.19 & 0.18 & 0.16 & 0.16 & 0.18 \\
\hline $\mathrm{C} 20: 4$ & 0.78 & 0.81 & 0.82 & 0.73 & 0.73 & 0.76 \\
\hline Total $n-6$ & 9.13 & 9.25 & 9.28 & 9.67 & 9.69 & 9.77 \\
\hline $\mathrm{C} 18: 3$ & 1.33 & 1.36 & 1.35 & 1.40 & 1.39 & 1.38 \\
\hline C18:4 & 1.56 & 1.54 & 1.55 & 1.39 & 1.40 & 1.42 \\
\hline $\mathrm{C} 20: 4$ & 0.70 & 0.72 & 0.68 & 0.63 & 0.64 & 0.64 \\
\hline C $20: 5$ & 9.32 & 9.35 & 9.39 & 7.73 & 7.66 & 7.82 \\
\hline C $22: 5$ & 1.86 & 1.89 & 1.85 & 1.53 & 1.64 & 1.56 \\
\hline C $22: 6$ & 13.13 & 13.18 & 13.21 & 10.78 & 10.80 & 10.73 \\
\hline Total n-3 & 27.90 & 28.04 & 28.03 & 23.46 & 23.53 & 23.55 \\
\hline $\mathrm{C} 22: 1 \mathrm{n} 11$ & 4.50 & 4.57 & 4.45 & 4.79 & 4.75 & 4.60 \\
\hline
\end{tabular}

group (5 fish per tank) were vaccinated with Vibrio anguillarum bacterin and placed in 6 new separate tanks. From these fish, blood samples for antibody titration were taken $4 \mathrm{wk}$ after vaccination. Head kidney, spleen, and thymus were also removed to determine vitamin $E$ levels and to perform chemiluminescence assays. The 20 fish remaining in each of the original tanks were experimentally infected with Vibrio anguillarum serotype 1 (strain 408, Baudin Laurencin 1981) to compare their resistance to the pathogen.

Blood sampling: Blood samples were collected in heparinized vacuum tubes (vacutainer ${ }^{\circledR}$ Becton Dickinson Vacutainer System) from the caudal vessel. Approximately $2 \mathrm{ml}$ of whole blood was taken from each fish. The blood was centrifuged $(3000 \times g, 10$ min) and the resulting plasma samples were collected and stored at $-70^{\circ} \mathrm{C}$ until analysis.

Experimental infection: Vibrio anguillarum broth culture was prepared as previously described by Obach et al. (1990). Fish were first anaesthetized with ethylene glycol monophenyl ether and then intraperitoneally injected with $0.2 \mathrm{ml}$ of a dilution of the virulent suspension $\left(5.5 \times 10^{6}\right.$ cells per fish). Deaths were recorded over an $8 \mathrm{~d}$ period. Dead fish were collected daily and necropsied. Kidney samples were cultured on tryptic soy agar (TSA), supplemented with $1.5 \%$ $\mathrm{NaCl}$, to verify the presence of $V$. anguillarum.

Vaccination: Ten fish from each dietary treatment 
were immunised intraperitoneally with $0.2 \mathrm{ml}$ of the vaccine 'Vibriffa injectable' (Mérieux). The vaccine is a formalized inactivated suspension of Vibrio anguillarum containing about $2 \times 10^{10}$ bacterial cells $\mathrm{ml}^{-1}$. Vaccinated fish were placed in 6 separate tanks and fed as before with the appropriate test diets for $4 \mathrm{wk}$. Water temperature at vaccination was $20^{\circ} \mathrm{C}$. A few days before sampling, all 10 fish in one tank fed the diet containing fresh oil and $300 \mathrm{mg}$ vitamin $\mathrm{E} \mathrm{kg}^{-1}$ diet died after a brief accidental increase in water temperature $\left(45^{\circ} \mathrm{C}\right.$ for 10 to $\left.15 \mathrm{~h}\right)$. Temperature remained constant in the other tanks.

Test methods. Haematological determinations: Haematocrit values were determined using the microhaematocrit technique and by centrifugation at $12000 \times g$ for $5 \mathrm{~min}$. Hacmoglobin concentration (Hb) was measured spectrophotometrically with a Compur $M 1000 D_{1}$ using the cyanmethemoglobin method. The red blood cell count ( $R B C C$ ) was made by adding blood to Gowas' solution and then analysed photometrically with a Compur M $1000 \mathrm{D}_{1}$ by measuring the turbidity. The mean corpuscular volume (MCV), mean corpuscular haemoglobin (MCH), and mean corpuscular haemoglobin concentration (MCHC) were calculated.

The erythrocyte fragility test was carried out as described by Drapers \& Csallany (1969). Fifty $\mu \mathrm{l}$ of whole blood was added to test tubes containing $\mathrm{pH} 7.4$ phosphate buffered saline (PBS), the tubes were incubated at $20^{\circ} \mathrm{C}$ for $24 \mathrm{~h}$, and the resulting haemolysis was measured photometrically.

Antibody production: Agglutination antibody titers were determined according to the microtitration technique described by Maisse \& Dorson (1976) for antiAeromonas salmonicida antibodies, but with slight modifications: the antigen, Vibrio anguillarum, was inactivated by heating $\left(100^{\circ} \mathrm{C}, 60 \mathrm{~min}\right)$ and resuspended in sterile physiological saline to an optical density of 1 at $625 \mathrm{~nm}$

Lysozyme assay: The turbidimetric assay for lysozyme was carried out according to Parry et al. (1965) as modified by Grinde et al. (1988). Briefly, test plasma $(100 \mu \mathrm{l})$ was added to $2 \mathrm{ml}$ of a suspension of Micrococcus lysodeikticus $(0.2 \mathrm{mg}$ per $\mathrm{ml}$ ) in a $0.05 \mathrm{M}$ sodium phosphate buffer, $\mathrm{pH}$ 6.2. The reactions were carried out at $20^{\circ} \mathrm{C}$ and absorbance at $520 \mathrm{~nm}$ was measured between 1 and $4 \mathrm{~min}$. A lysozyme activity unit was defined as the amount of enzyme producing a decrease in absorbance of $0.001 \mathrm{~min}^{-1}$ at $20^{\circ} \mathrm{C}$.

Total haemolytic complement assay: Complement activity was assayed using the procedure of Mayer (1971), with some modifications: total reaction volume and SRBC count were reduced 50 -fold (from 7.5 to $0.15 \mathrm{ml}$ and from $5 \times 10^{8}$ to $1 \times 10^{7} \mathrm{SRBC}$ ), to permit using microplates. SRBC were washed 3 times with phosphate buffered saline and resuspended to yield a $2 \%$ concentration $\left(2 \times 10^{8}\right.$ cells $\left.\mathrm{ml}^{-1}\right)$ in Hank's balanced salt solution (HBSS). SRBC were sensitised with heat-inactivated sea bass anti-SRBC serum, diluted to $1: 70$, a dilution permitting complete haemolysis (pers. obs.). SRBC were incubated with occasional shaking at $30^{\circ} \mathrm{C}$ for $30 \mathrm{~min}$. Test plasma samples were first diluted to $1 / 200$, then volumes of the diluted plasma $(0.01,0.02, \ldots 0.09 \mathrm{ml})$ were combined with $\operatorname{HBSS}(0.09$, $0.08, \ldots 0.01 \mathrm{ml}$ ) in the microplate and $0.05 \mathrm{ml}$ of sensitised SRBC were added per well. Complete haemolysis was obtained by mixing $0.05 \mathrm{ml}$ of sensitised SRBC with $0.1 \mathrm{ml}$ distilled water (positive control). After incubation at $20^{\circ} \mathrm{C}$ for $60 \mathrm{~min}$, microplates were centrifuged at $600 \times g$ for $5 \mathrm{~min}$. Optical density of supernatants was measured in a microplate reader (Argus 300 - Packard) at $490 \mathrm{~nm}$. A lysis curve was obtained by plotting the percentage of haemolysis against the volume of plasma added $(\mathrm{ml})$. The volume which yielded $50 \%$ haemolysis was determined and used for calculating the complement activity of the sample ( $\mathrm{CH} 50$ units $\mathrm{ml}^{-1}$ ) as follows (Sakai 1981):

$$
\begin{gathered}
\text { CH-50 unit } \mathrm{ml}^{-1}= \\
\frac{\text { Dilution coefficient of plasma }}{\mathrm{ml} \text { of } 50 \% \text { haemolysis }} \times \frac{0.15 \mathrm{ml}}{7.5 \mathrm{ml}}
\end{gathered}
$$

Natural haemolytic activity: The technique used was based on that of Chiller et al. (1969). Serial 2-fold dilutions of each sample $(50 \mu \mathrm{l})$ from sea bass were made on microtitration plates (Plaque microwell $96 \mathrm{U}$ Nunclon Delta) with HBSS. Fifty $\mu$ l of a $2 \%$ uncoated SRBC suspension was added to each well. The plates were incubated for $1 \mathrm{~h}$ at $20^{\circ} \mathrm{C}$ and then overnight at $4{ }^{\circ} \mathrm{C}$. Natural haemolytic activity was expressed as the reciprocal of the highest dilution yielding complete haemolysis.

Chemiluminescence assay: Head kidney cell suspensions were prepared as previously described by Angelidis et al. (1988). Head kidney was removed and pounded on a metallic filter (filtres Cellector Belco $100 \mu \mathrm{m})$. Cells were harvested, suspended in HBSS without phenol red, and kept on crushed ice. Leukocyte concentration was adjusted to $5 \times 10^{6}$ viable cells $\mathrm{ml}^{-1}$. Cell viability was evaluated by the trypan blue exclusion method. Luminol was prepared according to the method described by Scott \& Klesius (1981) to give a stock solution of $8 \mathrm{mM}$, and stored for a week at $4{ }^{\circ} \mathrm{C}$ in tubes wrapped in aluminium foil. Stock solutions were diluted 4 to $6 \mathrm{~h}$ before use in HBSS to obtain working solutions of $0.05 \mathrm{mM}$. The procedure for opsonizing zymosan was a modification of that used by Scott \& Klesius (1981). Zymosan and pooled serum from normal (non-experimental) fish were incubated together at $30^{\circ} \mathrm{C}$ for $45 \mathrm{~min}$. Zymosan 
Table 4. Dicentrarchus labrax. Vitamine E concentration ( $\mu \mathrm{g} \mathrm{g}^{-1}$ of fresh tissue) in head kidney, spleen, and thymus of sea bass fed 6 experimental diets for $39 \mathrm{wk}$. Data are expressed as the vitamin E concentration for pooled organs from 5 fish per diet ( 2 replicates)

\begin{tabular}{|c|c|c|c|c|c|c|c|}
\hline Organ & Replicate & $\mathrm{F}-0$ & $F-40$ & F-300 & $O x-0$ & $O x-40$ & $O x-300$ \\
\hline Head kidney & $\begin{array}{l}1 \\
2\end{array}$ & $\begin{array}{l}6.39 \\
4.27\end{array}$ & $\begin{array}{l}11.95 \\
14.92\end{array}$ & ND & $\begin{array}{l}1.10 \\
0.40\end{array}$ & $\begin{array}{l}4.73 \\
4.06\end{array}$ & $\begin{array}{l}33.75 \\
33.42\end{array}$ \\
\hline Spleen & $\begin{array}{l}1 \\
2\end{array}$ & $\begin{array}{l}6.90 \\
6.45\end{array}$ & $\begin{array}{l}11.60 \\
13.49\end{array}$ & ND & $\begin{array}{l}0.96 \\
1.18\end{array}$ & $\begin{array}{l}7.80 \\
5.90\end{array}$ & $\begin{array}{l}29.05 \\
30.23\end{array}$ \\
\hline Thymus & $\begin{array}{l}1 \\
2\end{array}$ & $\begin{array}{c}5.31 \\
4.55 \\
c\end{array}$ & $\begin{array}{c}11.00 \\
11.54 \\
b\end{array}$ & ND & $\begin{array}{c}0.65 \\
0.12 \\
d\end{array}$ & $\begin{array}{c}3.32 \\
3.34 \\
c\end{array}$ & $\begin{array}{c}37.23 \\
34.88 \\
\text { a }\end{array}$ \\
\hline
\end{tabular}

final concentration was $1 \mathrm{mg} \mathrm{ml}^{-1}$. Duplicate assay vials received $0.1 \mathrm{ml}$ cell suspension, $0.1 \mathrm{ml}$ opsonized zymosan, and $0.05 \mathrm{ml}$ luminol. Control vials were prepared by replacing zymosan with HBSS. Chemiluminescence (CL) values were recorded 6 times at $10 \mathrm{~min}$ intervals on a $1250 \mathrm{LKB}$ luminometer, to determine $\mathrm{CL}$ peak intensities.

Vitamin E determination: Endogenous dl-alpha-tocopherol levels were determined by the Buttriss \& Diplock (1984) method, with some modifications, previously described by Messager et al. (1992).

Statistical methods. For most of the parameters studied, the effect of each of the 2 factors quality of oil ( $F-1$ : fresh or oxidized) and level of vitamin $E$ supplementation (F-2: 0,40 or $300 \mathrm{mg} \mathrm{kg}^{-1}$ diet), as well as their interaction, were tested by a 2-way analysis of variance (ANOVA) based on the average of 7 fish per tank and 2 tanks per treatment $(\mathrm{n}=2)$ using a computerized STATITCF statistical system (ITCF, Boigneville, France). For endogenous vitamin E levels and antibody titers, due to the accidental loss of one entire experimental group (F-300), the effect of only 1 factor (diet) was tested by a 1-way ANOVA. When $\mathrm{p} \leq 0.05 \mathrm{a}$ Newman-Keuls test was applied. CL peak responses were compared using a Kruskall-Wallis non-parametric test, after rank transformation. When $\mathrm{p} \leq 0.05$, a Dunn test (Dunn 1964) was applied.

\section{RESULTS}

Endogenous vitamin E levels. Head kidney, spleen, and thymus vitamin $E$ levels reflected dietary input and were significantly decreased by the addition of oxidized oil to the diet (Table 4).

Haematology. The haematological measurements for fish fed the 6 experimental diets are shown in Table 5. Although fish fed the diet containing oxidized oil and no supplemental vitamin $E$ had lower haematocrit, haemoglobin, and RBCC values, no statistical differences were noted between the 6 experimental groups. Erythrocyte fragility (EF) was significantly affected by both factors: vitamin $\mathrm{E}$ depleted groups showed an increased EF when compared to those fed diets supplemented with 40 or $300 \mathrm{mg}$ vitamin $\mathrm{E} \mathrm{kg}^{-1}$ diet. EF was also increased in fish fed diets containing oxidized oil.

Plasma parameters (Table 6). Plasma lysozyme and complement activities were affected by both factors: fish oil quality and level of vitamin E supplementation. In fact, lysozyme activity was markedly higher in groups fed diets containing fresh oil and supplemented with 40 or $300 \mathrm{mg}$ vitamin $\mathrm{E} \mathrm{kg}^{-1}$ (significant interaction: $\mathrm{F}-300>\mathrm{F}-40>\mathrm{F}-0=\mathrm{Ox}-0=\mathrm{Ox}-40=\mathrm{Ox}-300$ ) and complement activity was higher in fish fed the diet containing fresh oil and $300 \mathrm{mg}$ vitamin $\mathrm{E} \mathrm{kg}^{-1}$ (significant interaction: $\mathrm{F}-300>\mathrm{F}-40=\mathrm{F}-0=\mathrm{Ox}-0=\mathrm{Ox}-40=$ Ox-300). Natural haemolytic activity was not influenced by either factor.

Experimental infection. Following challenge, deaths occurred from the 2nd to the 9th day. All dead fish were positive for Vibrio anguillarum and classic signs of haemorrhagic septicaemia were observed. The postchallenge mortality rates ranged from 78 to $90 \%$ and no statistically significant differences between the various diet groups were detected (Table 7).

Serum antibody. Before vaccination none of the fish sampled had detectable serum antibody $\left(\log _{2}\right.$ titer $\geq 2$ ) specific for Vibrio anguillarum. Vaccination resulted in substantial antibody production in all diet groups (mean $\log _{2}$ titer $=8.3$ ) but there were no significant differences in antibody responses among fish given the dietary treatments (Table 8).

Chemiluminescence. The CL response of head kidney phagocytes stimulated by opsonised zymosan increased progressively, reached a peak between 30 and $40 \mathrm{~min}$, and then decreased slightly. Zymosan-stimulated $C L$ responses were widely variable in all the experimental dietary groups. Basal activities for non- 


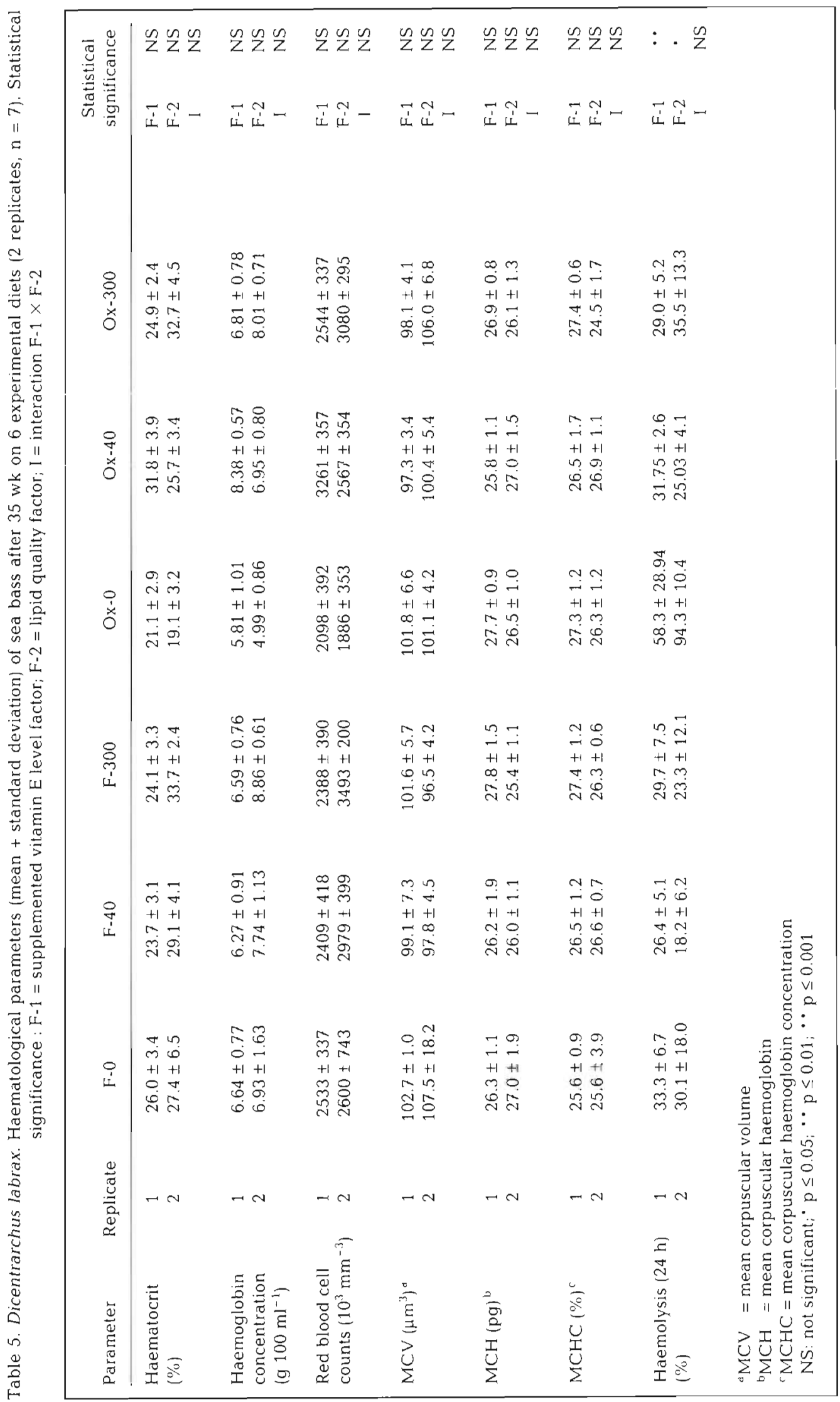




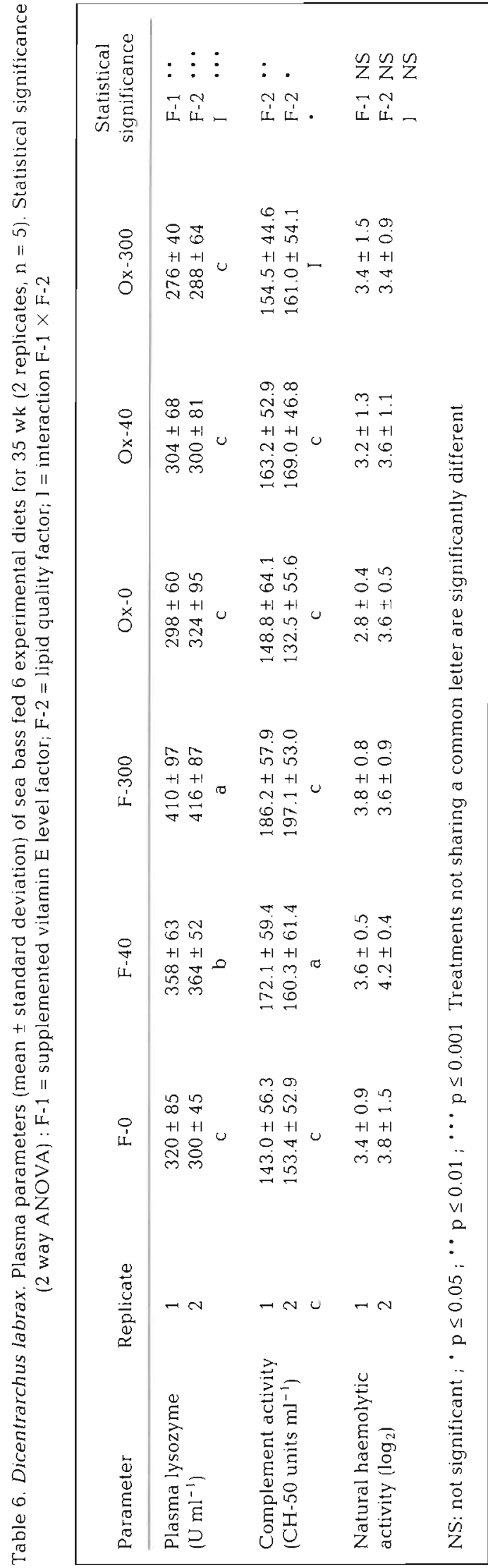

stimulated phagocytes were very low (always $<1 \mathrm{mV}$ ). CL peak responses were significantly lower in fish fed the diet containing oxidized oil and not supplemented with vitamin $E$, when compared with fish fed the diets with oxidized oil and $300 \mathrm{mg}$ vitamin $\mathrm{E} \mathrm{kg}^{-1}$ or fresh oil and $40 \mathrm{mg}$ vitamin $\mathrm{E} \mathrm{kg}^{-1}$ (Fig. 1).

\section{DISCUSSION}

Stéphan et al. (1991) showed that the fish in this experiment exhibited no differences in growth rate and other biometric parameters after being fed the experimental feed for $35 \mathrm{wk}$. Likewise, no obvious changes in health or behaviour were noted, and necropsy performed upon sampling did not yield any evidence of macroscopic lesions. However, these authors observed a degeneration of the muscle fibers, together with high aspartate amino transferase (ASAT) and creatine kinase (CK) activities, which they related to the level of thiobarbituric acid-reactive substances, a parameter frequently used to assess the oxidation level of lipids in vivo (Crastes de Paulet 1988) and to the tissue content of alpha-tocopherol. The muscle levels of alphatocopherol reflected dietary input and were clearly decreased by the addition of oxidized oil to the diet. The vitamin E concentrations in the haematopoietic organs were similarly affected.

Erythrocyte fragility was significantly increased by feeding a diet that contained a low level of alphatocopherol and/or oxidized lipids. This phenomenon has already been observed (Hung et al. 1981, Cowey et al. 1984) and may be the result of the structural role played by this vitamin in the cell membranes and/or of membrane phospholipid peroxidation. Indeed, beside its anti-oxidant function, alpha-tocopherol, through its structure which features a hydrophilic end and a long hydrophobic chain, is easily integrated within the cell membranes (Jore \& Ferradini 1988), where it can establish structural links with PUFA (Lucy 1974). Vitamin E deficiency could therefore be reflected by a change in membrane structure and increased fragility. In addition, as it has been shown in higher vertebrates, peroxidation of dietary PUFA results in the formation of hydroperoxides, followed by secondary auto-oxidation products (Kanazawa et al. 1985, Oarada et al. 1986) which can themselves induce endogenous lipid peroxidation (Minamoto et al. 1985, Kareda \& Minazawa 1987). Lipid peroxides can cause alteration of the cell membranes, as reflected by reduced fluidity, modification of permeability, and decompartmentalization (Jore \& Ferradini 1988). The levels of thiobarbituric acid-reactive substances noted in muscle indicated high lipid peroxidation in vivo, favourable to erythrocyte membrane degeneration. Such a fragility of eryth- 
Table 7. Dicentrarchus labrax. Mortality rate (\%) after experimental injection with Vibrio anguillarum 408 of sea bass fed 6 expermental diets for $35 \mathrm{wk}$ (2 replicates, $\mathrm{n}=20$ ). Statistical significance (2-way ANOVA). F-1 = supplemented vitamin $\mathrm{E}$ level factor; F-2 = lipid quality factor $; \mathrm{I}=$ interaction F-1 $\times$ F-2

\begin{tabular}{|c|c|c|c|c|c|c|c|c|c|}
\hline \multirow{3}{*}{$\begin{array}{c}\text { Mortality rate } \\
(\%)\end{array}$} & \multirow{3}{*}{$\begin{array}{c}\text { Replicate } \\
\begin{array}{c}1 \\
2\end{array}\end{array}$} & \multirow{3}{*}{$\begin{array}{l}F-0 \\
85.7 \\
77.8\end{array}$} & \multirow{2}{*}{$\begin{array}{l}F-40 \\
78.9 \\
90.5\end{array}$} & \multirow{2}{*}{$\frac{F-300}{84.2}$} & \multirow{2}{*}{$\begin{array}{l}\text { Ox-0 } \\
78.9\end{array}$} & \multirow{2}{*}{$\frac{O x-40}{85.0}$} & \multirow{2}{*}{$\begin{array}{c}\mathrm{Ox}-300 \\
84.2\end{array}$} & \multicolumn{2}{|c|}{$\begin{array}{l}\text { Statistical } \\
\text { significance }\end{array}$} \\
\hline & & & & & & & & $F-1$ & NS \\
\hline & & & 90.5 & 78.6 & 89.5 & 83.3 & 89.5 & $\begin{array}{l}\mathrm{F}-2 \\
\mathrm{I}\end{array}$ & $\begin{array}{l}\text { NS } \\
\text { NS }\end{array}$ \\
\hline
\end{tabular}

Table 8. Antibody titres (mean + standard deviation) of sea bass fed 6 experimental diets for 39 wk, 4 wk after vaccination with Vibrio anguillarum bacterin ( 2 replicates, $n=5$ )

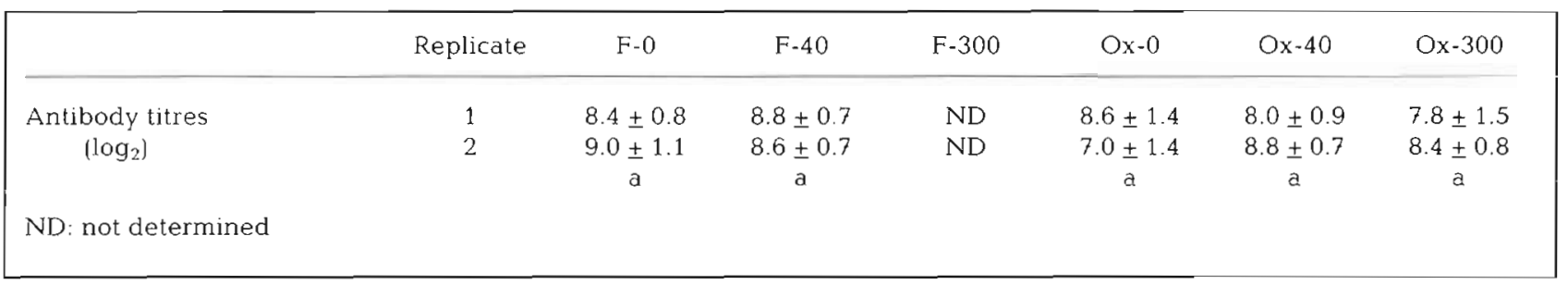

rocytes could facilitate the development of anaemia. While the statistical tests used did not reveal any significant differences, the fact remains that $\mathrm{RBCC}$, haematocrit, and haemoglobin were clearly lower in the fish fed the Ox-0 feed, indicating an anaemic tendency. This phenomenon is in agreement with the results obtained from similar experiments on other species such as rainbow trout (Smith 1979, Moccia et al. 1984) and catfish (Murai \& Andrews 1974).

Phagocyte activity of the head kidney leukocytes of fish fed the Ox-0 feed was significantly lower than noted in groups fed the $\mathrm{T}-40$ and $\mathrm{Ox}-300$ diets. A relationship appeared to exist between the chemiluminescence response and the tissue levels of alpha-tocophe- rol in the groups fed the diets with oxidized lipids, even if this relationship was not always significant. Blazer \& Wolke (1984) showed that rainbow trout fed alpha-tocopherol-deficient diets had lower phagocyte activities than those fed a diet containing $250 \mathrm{mg}$ vita$\min \mathrm{E} \mathrm{kg}^{-1}$. By contrast, in an experiment conducted by Hardie et al. (1990), the macrophage activity of Atlantic salmon was not altered by feeding a low alpha-tocopherol diet, and these authors suggested that the tissue concentration of vitamin $E$, although low, may have been sufficient to maintain leukocyte membrane integrity. Indeed, the same oxidative processes as those described for erythrocytes may exist for macrophages, and this may induce cell membrane

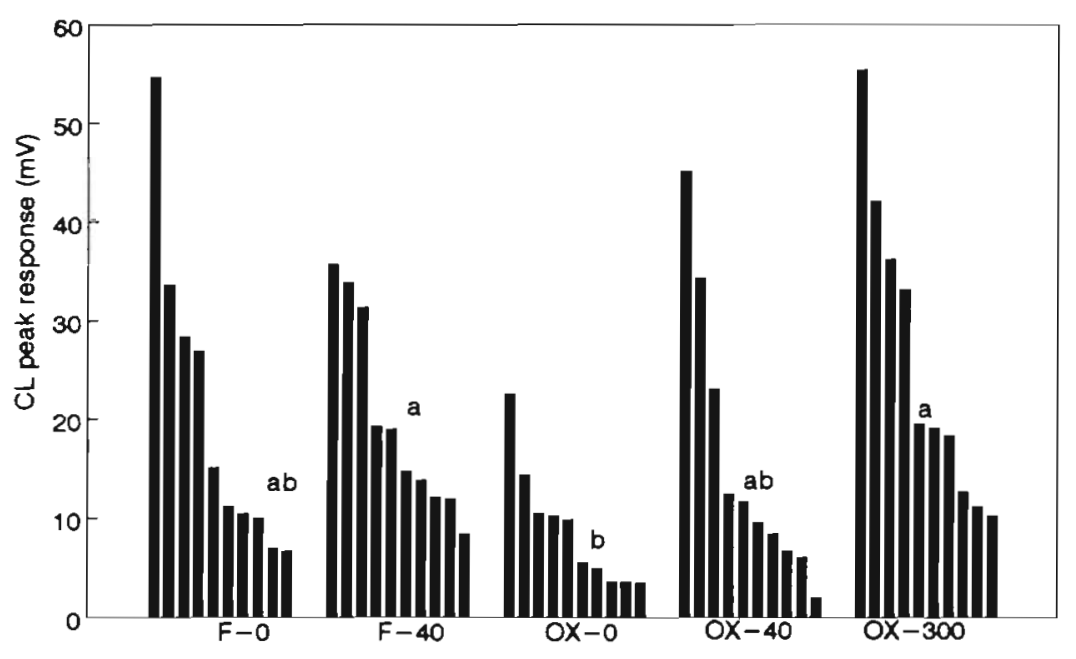

Fig. 1: Dicentrarchus labrax. Luminolenhanced chemiluminescence (CL) peak response of zymosan-stimulated head kidney phagocytes from sea bass fed various experimental diets for 39 wk (10 fish per diet). $\mathrm{CL}$ assay was performed $4 \mathrm{wk}$ after vaccination with Vibrio anguillarum vaccine. Groups sharing a common letter are not statistically different $(p<0.05)$ 
degradation. The macrophage membrane plays a key role in phagocytosis, and the changes in viscosity and permeability which may occur can alter cellular functions. Moreover, the macrophage membrane contains several receptors for the Fc fragment of immunoglobulins (Griffin 1983, Sakai 1984, Honda et al. 1985) and for the complement factor C3 (Johnson \& Smith 1984, Nonaka et al. 1984, Matsuyama et al. 1992). These factors favour antigen adhesion and engulfment and result in phagosome formation. Lastly, the membrane contains enzymes that are involved in the production of active forms of $\mathrm{O}_{2}$ (Chung \& Secombes 1988) and that are the source of chemiluminescence during the respiratory burst.

Plasma lysozyme activity also appears to be dependent on the 2 dietary factors. Vitamin E deficiency on the one hand, and supplementation of diets with oxidized lipids on the other, induce a decrease in the activity of the enzyme. In higher vertebrates, the biological effects of lipid peroxides may not only influence cell membrane function but also lead to the inhibition of certain enzymes (Kaneda \& Miyazawa 1987), probably due to the establishment of bonds between proteins and lipids at the level of sulphur amino-acids (Jore \& Ferradini 1988). Indeed, some oxidation products, in particular those with low molecular weight, may react with the thiol groups of certain enzymes and inhibit them (Schauenstein et al. 1977). Thus, Kanazawa et al. (1975) showed that linoleic acid oxidation products may inhibit lysozyme, in vitro, through selective destruction of certain amino-acids, including methionine.

The complement specific haemolytic activity also varied according to dietary treatment. The sea bass which received a diet containing non-oxidized lipids and supplemented with $300 \mathrm{mg}$ alpha-tocopherol per $\mathrm{kg}$ of feed had higher complement activity than found in the other experimental groups. Hardie et al. (1990) observed a similar phenomenon in Atlantic salmon. In this regard, the plasma from fish fed an alpha-tocopherol-deprived diet had lower total specific haemolytic activity and bacterial opsonizing capacity than the fish fed a diet supplemented with $326 \mathrm{mg} \mathrm{kg}^{-1}$ vitamin E. The mechanism of action of vitamin $\mathrm{E}$ and oxidized lipids on the complement activity is not known. However, the fact that macrophages are the site of production of some of the complement proteins suggests that an alteration of macrophage function caused by peroxidation of the membrane phospholipid fatty acids may alter the synthesis of some of these proteins.

Several studies have suggested that lysozyme (Fänge et al. 1976, Murray \& Fletcher 1976, Lundblad et al. 1979, Lindsay 1986, Grinde 1989), complement (Li \& Lovell 1985, Hardie et al. 1990, 1991), and phagocyte activity (Ellis 1981, MacArthur \& Fletcher 1985) play a major defensive role against infectious diseases and may constitute the first, and sometimes the most important, response of fish against bioaggressors (Blazer 1991). In this study, however, the variations of these 3 parameters due to different dietary treatments did not yield differences in survival of Vibrio anguillarum infection. This result can possibly be explained by the high challenge dose used (it killed 78 to $90 \%$ of the fish). Likely, this high dose overwhelmed the protective effect of the foregoing parameters. It is also possible that depression of some aspects of immunocompetence, although significant, may not have been marked enough to induce a measurable decrease in immune protection against the trial bacterium. Indeed, during a similar study on turbot (Obach \& Baudin Laurencin 1992), an increase in susceptibility to $V$. anguillarum was observed in fish fed a diet containing oxidized oil and not supplemented with vitamin $E$. In this case, however, the decrease in the immune parameters measured was much greater. In the present experiment, the influence of the various dietary treatments was not reflected by any variation in specific humoral response. Thus, macrophage and possible lymphocyte alterations were not sufficiently pronounced to prevent these cells from producing antibody. Forster et al. (1988) investigated the influence of dietary lipid oxidation and vitamin $E$ levels on performance and disease resistance in coho salmon Oncorhynchus kisutch. Immunocompetence, judged by antibody production in response to Vibrio vaccination, and mortality after experimental infection with $V$. anguillarum or $V$. ordalii were unaffected by the dietary treatments. Nevertheless, the fish did not suffer a vitamin $\mathrm{E}$ deficiency on any of the diets and the data did not preclude the possibility that significant dietary effects might have been identified if more fish had been employed or if fish had been reared at a higher water temperature.

After $35 \mathrm{wk}$ on the test diets, certain haematological and immunological parameters were modified, but only slightly. Similarly, the histopathological lesions and enzymatic variations observed by Stéphan et al. (1991) in relation to the dietary treatment of this study were moderate. Compared to salmonids (Hung et al. 1981, Cowey et al. 1984), sea bass may have lower needs for vitamin $E$, and they may be more resistant to dietary lipid oxidation (Baudin Laurencin et al. 1989).

Acknowledgements. A.O. was supported by a grant from the Spanish Ministry of Education and Science.

\section{LITERATURE CITED}

Angelidis, P., Baudin Laurencin, F., Youinou, P. (1988). Effects of temperature on chemiluminescence of phagocytes from sea bass, Dicentrarchus labrax L. J. Fish Dis. 11: 281-288 
Baudin Laurencin, F. (1981). Vibrio strains antisera in France. International Symposium on Fish Biologics: Serodiagnostics and Vaccines. Dev. biol. Stand. 49: 257-259

Baudin Laurencin, F., Messager, J L., Stéphan, G. (1989). Two examples of nutritional pathology related to vitamin $\mathrm{E}$ and $\mathrm{C}$ deficiencies. Advances in Tropical Aquaculture, Aquacop. IFREMER, Actes de Colloques 9: $171-181$

Blazer, V. S., Wolke, R. E. (1984). The effects of alpha-tocopherol on the immune response and non-specific resistance factors of rainbow trout (Salmo gairdneri Richardson). Aquaculture 37: 1-9

Blazer, V. S. (1991). Piscine macrophage function and nutritional influences: a review. J. aquat. Anim. Hlth 3(2): $77-86$

Buttriss, J. L., Diplock, A. T. (1984). High performance liquid chromatography methods for vitamin $\mathrm{E}$ in tissues. Meth. Enzymol. 105: 131-147

Chiller, J M, Hodgins, H O. Weiser, R S (1969) Antibody response in rainbow trout (Salmo gairdneri) - II. Studies on the kinetics of development of antibody-producing cells and on complement and natural haemolysin. J. Immunol. 102(5): 1202-1207

Chung, S., Secombes, C. J. (1988). Analysis of events occurring within teleost macrophages during the respiratory burst. Comp. Biochem. Physiol. 89B(3): 539-544

Corwin, L. M., Gordon R. K. (1982). Vitamin E and immune regulation. Ann. N. Y. Acad. Sci. 393: 437-451

Cowey, C. B., Degener, E., Tacon, A. G. L., Youngson, A., Bell, J. G. (1984). The effect of vitamin $E$ and oxidized fish oil on the nutrition of rainbow trout (Salmo gairdnern) grown at natural varying water temperatures. Br. J. Nutr. 81: $443-451$

Crastes de Paulet, A. (1988). Peroxydation des lipides tissulaires: méthodes d'évaluation. Analyse critique. In: Douste-Blazy, L., Mendy, F. (eds.) Biologie des lipides chez l'homme. De la physiologie à la pathologie. CNRSCNERNA, Editions Médicales Internationales, Paris, p. $229-249$

Dunn, O. J. (1964). Multiple comparisons using rank sums. Technometrics 6(3): 241-252

Draper, H. H., Csallany, A. S. (1969). A simplified haemolysis test for vitamin E deficiency. J. Nutr. 98: 390-394

Ellis, A. E. (1981). Non-specific defense mechanisms in fish and their role in disease processes. Dev. biol. Stand. 49: $337-352$

Fänge, R., Lundblad, G., Lind, J. (1976). Lysozyme and chitinase in blood and lymphomyeloid tissues of marine fish. Mar. Biol. 36: 277-282

Forster, I., Higgs, D. A., Bell, G. R., Donsanjh, B. S., March, B. E. (1988). Effect of diets containing herring oil oxidized to different degrees on growth and immunocompetence of juvenile coho salmon (Oncorhynchus kisutch). Can. J Fish. Aquat. Sci. 45: 2187-2194

Griffin, B. R. (1983). Opsonic effect of rainbow trout (Salmo gairdneri) antibody on phagocytosis of Yersinia ruckeri by trout leukocytes. Dev. comp. Immunol. 7: 253-259

Grinde, B., Jollès, J., Jollès, P. (1988). Purification and charac. terization of two lysozymes from rainbow trout (Salmo gairdneri). Eur. J. Biochem. 173: 269-273

Grinde, B. (1989). Lysozyme from rainbow trout, Salmo gairdneri Richardson, as an antibacterial agent against fish pathogens. J. Fish Dis. 12: 95-104

Hata, K., Fujimoto, K., Kaneda, T (1986). Absorption of lipid hydroperoxides in carp. Bull. Jap. Soc. scient. Fish. 52(4): $677-684$

Hardie, L. J., Fletcher, T C., Secombes, C. J. (1990). The ef- fect of vitamin $E$ on the immune response of the Atlantic salmon (Salmo salar). Aquaculture 87: 1-13

Hardie, L. J., Fletcher, I C., Secombes, C. J. (1991). The effect of dietary vitamin $\mathrm{C}$ on the immune response of the Atlantic salmon (Salmo salar L.). Aquaculture 95: $201-214$

Heinzerling, R. H., Tengerdy, R. P., Wick, L. L., Lueker, D. C. (1974). Vitamin E protects mice against Diplococcus pneumoniae type I infection. Infect. Imm. 10(6): 1292-1295

Honda, A., Kodama, H., Moustafa, M., Yamada, F., Mikami, T., Izawa, H. (1985). Response of rainbow trout immunized with formalin-killed Vibrio anguillarum: activity of phagocytosis of fish macrophages and opsonizing effect of antibody. Fish Pathol. 20(2/3): 395-402

Hung, S. S. O., Cho, C. Y., Slinger, S. J. (1981). Effect of oxidized fish oil, DL-alpha-tocopherol acetate and ethoxyquin supplementation, on the vitamin $E$ nutrition of rainbow trout (Salmo gairdneri) fed practical diets. J. Nutr $111.648-657$

Johnson, E., Smith, P. (1984). Attachment and phagocytosis by salmon macrophages of agarose beads coated with human C3bi. Dev. comp. Immunol. 8: 623-630

Jore, D., Ferradini, C. (1988). Péroxydation lipidique: rôle des radicaux libres et régulation par les vitamines $\mathrm{E}$ et $\mathrm{C}$. In Douste-Blazy, L., Mendy, F. (eds.) Biologie des lipides chez l'homme. De la physiologie à la pathologie. CNRSCNERNA, Editions Médicales Internationales, Paris, p. $125-136$

Kanazawa, K., Danno, G.-I., Natake, M. (1975). Lysozyme damage caused by secondary degradation products during the autoxidation process of linoleic acid. $J$. nutr. Sci. Vitaminol. 21: 373-382

Kanazawa, K., Kanazawa, E., Natake M. (1985). Uptake of secondary autoxidation products of linoleic acid by the rat. Lipids 20(7): 412-419

Kaneda, T., Miyazawa, T. (1987). Lipid peroxides and nutrition. Wld Rev. Nutr. Diet. (Karger, Basel) 50: 186-214

Lall, S. P. (1988). Disease control through nutrition. Congress Proceedings of Aquaculture International Congress \& Exposition (September 6-9, 1988), Vancouver, p. 607-610

Li, Y., Lovell, R. T (1985). Elevated levels of dietary ascorbic acid increase immune responses in channel catfish. $J$. Nutr. 115: 123-131

Likoff, R. O., Guptill, D. R., Lawrence, L. M., McKay, C. C., Mathias, M. M., Nockels, C. F., Tengerdy, R. P. (1981). Vitamin $E$ and aspirin depress prostaglandins in protection of chickens against Escherichia coli infection. Am. J. clin. Nutr. 34: 245-251

Lindsay, G. J. H. (1986). The significance of chitinolytic enzymes and lysozyme in rainbow trout (Salmo gairdneri) defence. Aquaculture 51: 169-173

Lucy, J. A. (1974). Functional and structural aspects of biological membranes: a suggested role for vitamin $E$ in the control of membrane permeability and stability. Ann. N.Y. Acad. Sci. 258: 4-11

Lundblad, G., Fänge, R., Slettengren, K., Lind, J. (1979). Lysozyme, chitinase and exo-N-Acetyl-B-D-Glucosaminidase (NAGase) in lymphomyeloid tissue of marine fishes. Mar. Biol. 53: 311-315

MacArthur, J. I, Fletcher, T. C. (1985). Phagocytosis in fish. In: Manning, M. J., Tatner, M. F. (eds.) Fish immunology. Academic Press, London, p. 29-46

Maisse, G., Dorson, M. (1976). Production d'agglutinines antiAeromonas salmonicida par la truite arc-en-ciel. Ann. Rech. Vétér. 7(4): 307-313

Matsuyama, H., Yano, T., Yamakawa, T., Nakao, M. (1992) Opsonic effect of the third complement component (C3) of 
carp (Cyprinus carpio) on phagocytosis by neutrophils. Fish Shellfish Immunol. 2: 69-78

Mayer, M. M. (1971). Complement and complement fixation. In: Kabat, E. A. (ed.) Experimental immunochemistry. Charles C. Thomas, Springfield, p. 133-240

Messager, J. L., Stéphan, G., Quentel, C., Baudin Laurencin, F. (1992). Effects of dietary oxidized fish oil and antioxidant deficiency on histopathology, haematology, tissue and plasma biochemistry of sea bass Dicentrarchus labrax. Aquat. Living Res. 5(3): 205-214

Minamoto, S., Kanazawa, K., Ashida, H., Danno, G.-I., Natake, M. (1985). The induction of lipid peroxidation in rat liver by oral intake of 9-Oxononanoic acid contained in autoxidized linoleic acid. Agric. Biol. Chem. 49(9): 2747-2751

Moccia, R. D., Hung, S. S. O., Slinger, S. J., Ferguson, H. W. (1984). Effect of oxidized fish oil, vitamin $E$ and ethoxyquin on the histopathology and haematology of rainbow trout Salmo gairdneri Richardson. J. Fish Dis. 7: $269-282$

Murai, T., Andrews, J. W. (1974). Interactions of dietary alpha-tocopherol, oxidized Menhaden oil and ethoxyquin on channel catfish (Ictalurus punctatus). J. Nutr. 104: $1416-1431$

Murray, C. K., Fletcher, T. C. (1976). The immunohistochemical localization of lysozyme in plaice (Pleuronectes platessa L.) tissues. J. Fish Biol. 9: 329-334

Nockels, C. F. (1979). Protective effects of supplemental vitamin E against infection. Fed. Proc. 38: 2134-2138

Nonaka, M., Iwaki, M., Nakai, C., Nozaki, M., Kaidoh, T., Nonaka, M., Natsuume-Sakai. S., Takahashi, M. (1984). Purification of a major serum protein of rainbow trout (Salmo gairdneri) homologous to the third component of mammalian complement. J. Biol. Chem. 259: 6327-6333

Oarada, M., Miyazawa, T., Kaneda, T. (1986). Distribution of ${ }^{14} \mathrm{C}$ after oral administration of $\left(\mathrm{U}-{ }^{14} \mathrm{C}\right)$ labeled methyl linoleate hydroperoxides and their secondary oxidation products in rats. Lipids $21(2): 150-154$

Obach, A., Vigneulle, M., Baudin Laurencin, F. (1990). A practical method for determining the virulence of a Vibrio anguillarum broth culture to be used in experimental challenge. In: Lésel, R. (ed.) Microbiology of Poecilotherms. Elsevier Science Publishers (Biomedical Division), Amsterdam, p. 269-272

Obach, A., Baudin Laurencin, F. (1992). Effects of dietary oxidized fish oil and anti-oxidants deficiency on the immune response of turbot, Scophthalmus maximus. Aquaculture 107: 221-228.

Responsible Subject Editor: T. Evelyn, Nanaimo, B.C. Canada
Parry, R. M., Chandon, R. C., Shahani, K. M. (1965). A rapid and sensitive assay of muramidase. Proc. Soc. exp. Biol. Med. 119: 384-386

Person-Le Ruyet, J., Baudin Laurencin, F., Devauchelle, N., Métailler, R., Nicolas, J. L., Robin, J., Guillaume, J. (1990). Culture of turbot (Scophthalmus maximus). In: McVey, J. P. (ed.) Handbook of mariculture, Vol. II. Finfish aquaculture. CRC Press, Boca Raton, p. 21-41

Poston, H. A., Combs, G. F., Leibovitz, L. (1976). Vitamin E and selenium interrelations in the diet of Atlantic salmon (Salmo salar) gross, histological and biochemical deficiency signs. J. Nutr. 106: 892-904

Sakai, D. K. (1981). Spontaneous and antioody-dependent haemolysis activities of fish sera and inapplicability of mammalian complements to the immune haemolysis reaction of fishes. Bull. Jap. Soc. scient. Fish. 47(8): 979-991

Sakai, D. K. (1984). Opsonization by fish antibody and complement in the immune phagocytosis by peritoneal exudate cells isolated from salmonid fishes. J. Fish Dis. 7 : $29-38$

Schauenstein, E., Esterbauer, H., Zollner, H. (1977). In: Lagnado, J. R. (ed.) Aldehydes in biological systems. Pion Limited, London, p. 42-51

Scott, A. L., Klesius, P. H. (1981). Chemiluminescence : a novel analysis of phagocytosis in fish. In: International Symposium on Fish Biologics: Serodiagnostics and Vaccines. Dev. biol. Stand. 49, p. 243-254

Smith, C. E. (1979). The prevention of liver lipid degeneration (ceroidosis) and microcytic anaemia in rainbow trout (Salmo gairdnen Richardson) fed rancid diets: a preliminary report. J. Fish Dis. 2: 429-437

Stéphan, G., Messager, J. L., Baudin Laurencin, F., Lamour, F. (1991). Incidence chez le bar Dicentrarchus labrax d'aliments contenant des lipides oxydés et carences ou non en vitamine E. In: Kaushik, S. J., Luquet, P. (eds.) Proc. IV International Symposium on Fish Nutrition and Feeding. INRA, Paris (in press)

Tengerdy, R. P., Heinzerling, R. H., Brown, G. L., Mathias, M. M. (1973). Enhancement of the humoral immune response by vitamin E. Int. Arch. Allergy appl. Immunol. 44: $221-232$

Watanabe, T., Takashima, F., Ogino, C., Hibiya, T. (1970). Effects of alpha-tocopherol deficiency on carp. Bull. Jap. Soc. scient. Fish. 36: 623-630

Woodall, A. N., Ashley, L. M., Halver, J. E., Olcott, H. S., Van Der Veen, J. (1964). Nutrition of salmonid fishes. XIII. The alpha-tocopherol requirement of chinook salmon. J. Nutr. $84: 125-135$

Manuscript first received: November 1, 1992

Revised version accepted: January 10, 1993 